\title{
A comparative study on growth, protein turnover and energy budget of green and white color morphs of sea cucumber Apostichopus japonicus (Selenka)
}

\author{
Bin Xia ${ }^{1}$, Yichao Ren ${ }^{1}$, Fei Wang ${ }^{2, *}$, Dan $\mathrm{Yu}^{1,3}$, Guoping Cui ${ }^{2}$, Jinghua Chen ${ }^{1}$ \\ ${ }^{1}$ Marine Science and Engineering College, Qingdao Agricultural University, Qingdao, Shandong Province 266109, PR China \\ ${ }^{2}$ Key Laboratory of Marine Ecological Restoration, Shandong Marine Resource and Environment Research Institute, Yantai, \\ Shandong Province 264006, PR China \\ ${ }^{3}$ Qingdao Agricultural University Library, Qingdao, Shandong Province 266109, PR China
}

\begin{abstract}
A 98 d experiment was conducted to compare the growth performance, protein turnover and energy budget between green and white color morphs of the sea cucumber Apostichopus japonicus. During the experiment, sea cucumbers were fed a single natural diet of Sargassum thunbergii and a premixed artificial diet. Results showed that there was no significant interaction of diet, species or experimental time on growth performance and feed utilization of $A$. japonicus. Specific growth rate (SGR) of green sea cucumber was significantly higher than that of white sea cucumber. Green sea cucumber fed $S$. thunbergii exhibited much higher food conversion efficiency (FCE) and protein efficiency ratio (PER) compared to those on the artificial diet, indicating preferential absorption of $S$. thunbergii. There were also significant discrepancies in body wall production rate (BWPR), crude protein and ash content between green and white sea cucumber. The observed $\delta^{15} \mathrm{~N}$ values gradually increased owing to the assimilation of the diets containing higher nitrogen stable isotope ratios. Green sea cucumber reflected and approached $\delta^{15} \mathrm{~N}$ values of the experimental diets much more quickly and with shorter half-lives than white sea cucumber. The relatively constant metabolic contributions in intestine (71 to $78 \%$ ) and body wall (46 to $52 \%$ ) of sea cucumber indicated a stable bioenergetic distribution strategy of tissue. According to the time-based turnover model, the estimated fractionation $\left(\Delta^{15} \mathrm{~N}\right)$ ranged from 2.37 to $3.30 \%$. The average formulas of energy allocation for green and white sea cucumber were: $100 C=7.8 G+53.1 F+6.2 U+32.8 R, 100 C=6.3 G+57.9 F+8.9 U+27.0 R$, respectively. Taken together, our results suggest that white sea cucumber may have higher dietary quality requirements for growth and metabolism than green sea cucumber.
\end{abstract}

KEY WORDS: Apostichopus japonicus - Growth - Nitrogen stable isotope · Protein turnover · Energy allocation

\section{INTRODUCTION}

The sea cucumber Apostichopus japonicus (Selenka) (Echinodermata: Holothuroidea) traditionally has been used as a remedy for wound healing due to its curative and aphrodisiac effects (Sloan 1984, Xia et al. 2013a). With increasing market demand and decreasing natural resources available to A. japonicus, the farming scale has been expanded rapidly in

${ }^{*}$ Corresponding author: wangfei8230393@163.com the last few decades, especially in Shandong, Liaoning and Fujian provinces in China (Sun et al. 2012). Total production of this species reached $206000 \mathrm{t}$ in 2015, a $101 \%$ increase compared to that in 2009 (MOAC 2016). However, long-term inbreeding and unsustainable brood-stock culture has resulted in serious problems, including breed deterioration and disease (Gao et al. 2011, Zheng et al. 2012). Therefore, selecting fine breeding lines has become the top

(C) The authors 2017. Open Access under Creative Commons by Attribution Licence. Use, distribution and reproduction are unrestricted. Authors and original publication must be credited. 
priority for the sustainable culture of sea cucumber (Bai et al. 2015).

Color variation is an important and particular characteristic for sea cucumber. Previous studies have shown that sea cucumber can be divided into green, red and black morphs (Kanno et al. 2006, Kang et al. 2011). White sea cucumber, a genetic albino variant, is rare in nature (Ma et al. 2014a) and extensively believed to be rich in the element selenium, and consequently has a high market value. Therefore, it would be fascinating to foster this commercial species in aquaculture practice. With successful hatchery and semi-intensive culture techniques that are currently used, the production of white sea cucumber is increasing year by year in China. Previous studies have mainly focused on physiological performance (Pei et al. 2012, Lin et al. 2013) and genetics (Ma et al. $2014 \mathrm{a}, \mathrm{b}$ ); however, there is little information on nutritional characteristic and energy allocation of white sea cucumber.

As a typical deposit-feeding species, sea cucumber mainly take up detritus of sea grass and macroalgae, benthic microalgae, protozoa and bacteria as food sources in the sediment of natural seawater (Xia et al. 2015a). In aquaculture practice, macroalgae powder consisting of Sargassum thunbergii, Gracilaria lemaneiformis or Laminaria japonica is generally provided as a supplement to sea cucumber (Gao et al. 2011). Recently, a range of physicochemical and biological tests were conducted to assess the suitability of terrestrial plant protein sources, e.g. soybean meal (Seo \& Lee 2011, Seo et al. 2011) and corn leaf (Wu et al. 2015), as a replacement for seaweeds. Sea cucumber generally requires a relatively low energy supply for optimum growth (Sun et al. 2004, Zhu et al. 2005). Stable isotope analysis can effectively yield valuable information on the incorporation of micro- and macronutrients (Le Vay \& Gamboa-Delgado 2011, MartinPerez et al. 2013, Xia et al. 2015b). In the present study, we compared the discrepancies of growth, protein turnover and energy budget of green and white sea cucumber under different dietary regimes, to provide scientific basis for further study on the physiological ecology and nutriology of sea cucumber.

\section{MATERIALS AND METHODS}

\section{Experimental design}

Juvenile green and white sea cucumbers of initial dry weight $0.44 \pm 0.01 \mathrm{~g}$ were collected from a commercial farm in Yantai City. To ensure complete turnover of nitrogen stable isotope and subsequent homogeneous isotopic composition at the beginning of the experiment, the sea cucumbers were fed the same diet for 6 mo (Xia et al. 2015a). The sea cucumbers were then immediately transported to the laboratory and acclimated to the experimental conditions for $3 \mathrm{wk}$ at salinity 30 to 32 , dissolved oxygen $6.5 \mathrm{ml}$ $\mathrm{I}^{-1}$, temperature $20 \pm 0.5^{\circ} \mathrm{C}$ and a photoperiod of $14 \mathrm{~h}$ light:10 h dark (Sun et al. 2012, Xia et al. 2017). After acclimation, the green and white sea cucumbers were equally divided into 2 groups, respectively. Each group contained 120 sea cucumbers that were randomly allocated into 3 glass aquaria $(50 \times 60 \times$ $60 \mathrm{~cm}^{3}, 180$ l), i.e. 40 ind. aquarium ${ }^{-1}$.

Sea cucumbers in each group were fed a single natural diet $(80 \%$ Sargassum thunbergii and $20 \%$ sea mud) and premixed artificial diet, respectively. The artificial diet contained fish meal, soybean meal and kelp powder as protein sources (Table 1). To comply with the feeding habits of sea cucumber, sea mud was collected from an intertidal zone, dried and ground to fine powder. Then it was combusted at $550^{\circ} \mathrm{C}$ for $6 \mathrm{~h}$ to remove organic matter. All ingredi-

Table 1. Formulation and nutritional composition of the experimental diets (dry matter, \%)

\begin{tabular}{|c|c|c|}
\hline Ingredient & $\begin{array}{c}\text { Single } \\
\text { natural } \\
\text { diet }\end{array}$ & $\begin{array}{l}\text { Premixed } \\
\text { artificial } \\
\text { diet }\end{array}$ \\
\hline Sargassum thunbergii & 80 & / \\
\hline Fish meal & / & 6.0 \\
\hline Soybean meal & / & 22.0 \\
\hline Gelatinized cornstarch & / & 20.0 \\
\hline Kelp powder & / & 8.0 \\
\hline Wheat starch & / & 6.0 \\
\hline Squid liver oil & / & 0.5 \\
\hline Lecithin & / & 0.5 \\
\hline Mineral premix ${ }^{a}$ & / & 1.0 \\
\hline Vitamin premix ${ }^{b}$ & / & 1.0 \\
\hline Sea mud & 20 & 35.0 \\
\hline \multicolumn{3}{|l|}{ Proximate analysis } \\
\hline Crude protein & 15.71 & 16.03 \\
\hline Energy $\left(\mathrm{kJ} \mathrm{g}^{-1}\right)$ & 11.58 & 11.76 \\
\hline$\delta^{15} \mathrm{~N}(\%)$ & 9.78 & 4.12 \\
\hline \multicolumn{3}{|c|}{ 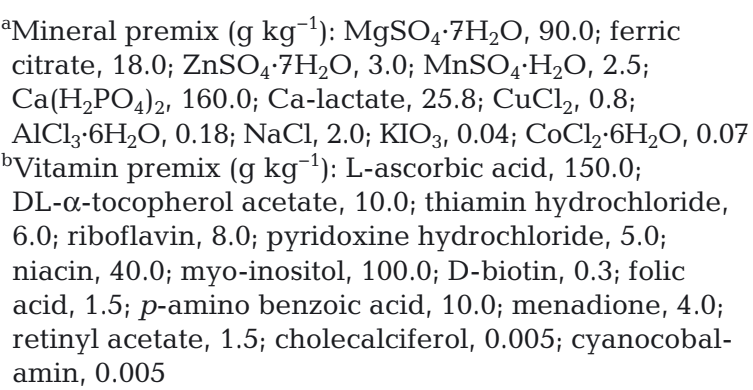 } \\
\hline
\end{tabular}


ents were blended thoroughly with $30 \%$ distilled water. Pellets were made with a moist pelletizer, dried for $24 \mathrm{~h}$ in an oven at $60^{\circ} \mathrm{C}$, ground into desirable sizes (180 meshes), and stored at $-20^{\circ} \mathrm{C}$ for use.

The experiment lasted for $98 \mathrm{~d}$. During the experiment, the sea cucumbers were fed up to $5 \%$ of their total biomass once per day at 17:00 $\mathrm{h}$. This ration size ensured satiation and minimized feed waste (Liu et al. 2009, Xia et al. 2015a). Uneaten feed and feces were collected separately by siphoning $22 \mathrm{~h}$ after feeding, and dried at $60^{\circ} \mathrm{C}$ to a constant weight for further analysis. The weight of uneaten feed was adjusted by the leaching ratio of the diet in water (Shi et al. 2015).

\section{Sample collection and determination}

On Day $0,7,14,28,42,70$ and 98,3 sea cucumbers from each aquarium were randomly sampled. After being weighed, all individuals were dissected on ice, and the intestine and body wall were separated immediately. All samples were dried, ground and stored at $-80^{\circ} \mathrm{C}$ for further analysis.

Nitrogen stable isotope values were measured by an EA-IRMS (ThermoFinnigan MAT Delta-plus). Results are expressed in standard $\delta$-unit notation, defined as follows:

$$
\delta^{15} \mathrm{~N}=\left[\left(R_{\text {sample }} / R_{\text {standard }}\right)-1\right] \times 1000 \%
$$

where $R$ is ${ }^{15} \mathrm{~N}:{ }^{14} \mathrm{~N}$. The ratios were reported compared to air $\mathrm{N}_{2}$. Analytical precision was $\pm 0.1 \%$.

At the end of the experiment, the sea cucumbers were fasted for $24 \mathrm{~h}$, and collectively weighed and counted for calculations of survival, growth performance and feed utilization. Proximate composition was determined by the standard methods of AOAC (1995). The Kjeldahl method after acid digestion was used to analyze crude protein $(\mathrm{N} \times 6.25)$; crude lipid was measured by the ether-extraction method. The energy and nitrogen contents of all samples were determined by a calorimeter (PARR Instrument) and a CHNS/O Analyzer (PE2400 Series II; PerkinElmer), respectively.

\section{Time-based turnover model}

Temporal changes in nitrogen stable isotope ratios of sea cucumber were modeled as an exponential function (Sun et al. 2012), represented as follows:

$$
\delta_{t}=\delta_{\mathrm{f}}+\left(\delta_{\mathrm{i}}-\delta_{\mathrm{f}}\right) \mathrm{e}^{-(k+m) t}
$$

where $\delta_{t}$ is the measured isotopic signature at experimental time $t, \delta_{\mathrm{f}}$ is the expected isotopic signature in equilibrium with the diet, $\delta_{\mathrm{i}}$ is the initial isotopic signature, and $m$ is the metabolic turnover constant. The growth rate constant $(k)$ was calculated using the following equation (Xia et al. 2013b):

$$
k=\ln \left(W_{\mathrm{f}} / W_{\mathrm{i}}\right) / t
$$

where $W_{\mathrm{f}}$ is the final dry weight of sea cucumber at sampling time $t$ and $W_{\mathrm{i}}$ is the initial dry weight at $t=0$. Expected isotopic change due to growth alone was determined by Eq. (2) where $m$ was set to 0 , while isotopic turnover due to metabolism was derived by comparing expected isotopic turnover owing to growth with the observed turnover during the experiment. Any isotopic turnover in excess of what was contributable to growth was caused by metabolic tissue replacement $(m)$, estimated using non-linear regression.

The relative contributions of growth $\left(P_{\mathrm{g}}\right)$ and metabolism $\left(P_{\mathrm{m}}\right)$ to nitrogen isotopic turnover were expressed as the following equation (Buchheister \& Latour 2010):

$$
P_{\mathrm{g}}\left(\text { or } P_{\mathrm{m}}\right)=k(\text { or } m) /(k+m)
$$

Nitrogen isotopic fractionation was calculated as follows (Gamboa-Delgado et al. 2013):

$$
\Delta=\delta_{\mathrm{f}}-\delta_{\mathrm{d}}
$$

where $\delta_{\mathrm{d}}$ is the $\delta^{15} \mathrm{~N}$ value of the diet. The period needed to achieve an $\alpha$ percent isotopic turnover (Hesslein et al. 1993) was calculated as follows:

$$
T_{\alpha / 100}=-\ln (1-\alpha / 100) /(k+m)
$$

To determine half-life $\left(T_{0.5}\right)$, the equation was solved for $\alpha=50$.

\section{Energy budget}

Energy allocation was constructed by the following equation (Liu et al. 2009):

$$
C=G+F+U+R
$$

where $C$ represents energy consumed, $G$ is energy for growth, $F$ is energy of feces produced, $U$ stands for energy loss as ammonia excretion, $R$ is energy loss as respiration $\left(\mathrm{kJ} \mathrm{g}^{-1} \mathrm{~d}^{-1}\right)$. $U$ was estimated by the nitrogen budget equation (Shi et al. 2013):

$$
U=\left(C_{\mathrm{N}}-G_{\mathrm{N}}-F_{\mathrm{N}}\right) \times 24830
$$

where $C_{\mathrm{N}}$ is nitrogen consumed from diet, $G_{\mathrm{N}}$ is nitrogen deposited in body, $F_{\mathrm{N}}$ is nitrogen lost in feces, and 24830 is the energy content in excreted ammonia $\left(\mathrm{J} \mathrm{g}^{-1}\right)$. The value of $R$ was calculated by $R$ $=C-G-F-U$. 


\section{Statistical analysis}

A 3-way analysis of variance (ANOVA) was used to examine the interaction of diet, color morph and experimental time on growth, survival, feed utilization and proximate composition of Apostichopus japonicus, while the parameters based on the turnover model of $\delta^{15} \mathrm{~N}$ (e.g. $m, P_{g}, T_{0.5}$, etc.) and energy parameters of sea cucumber were analyzed by 2 -way ANOVA. The discrepancies in parameters between the diet treatments and between the color morphs were compared using paired Student's $t$-tests. A probability level of 0.05 was used for rejection of the null hypothesis. Prior to analysis, raw data were examined for normality of distribution and homogeneity of variance with Kolmogorov-Smirnov and Levene's tests, respectively (Zar 1999). All statistical analyses were performed with software SPSS (2008). Data are mean $\pm \mathrm{SD}$.

\section{RESULTS}

\section{Growth performance and feed utilization}

Three-way ANOVA showed that there was no significant interaction of diet, species and experimental time on growth performance and feed utilization of Apostichopus japonicus (Table 2). However, significant interactions of species and experimental time on $W_{\mathrm{f}}$, weight gain and protein efficiency ratio (PER) of sea cucumber were found during the $98 \mathrm{~d}$ experiment $(p<0.05)$. Individuals increased in average dry weight by 61.09 to $66.92 \%$ and 45.46 to $47.91 \%$ for green and white sea cucumber, respectively. Green sea cucumber had higher specific growth rates (SGRs) compared to white sea cucumber, and the SGRs of green sea cucumber fed Sargassum thunbergii were significantly higher than those fed the artificial diet $(p<0.05)$. Food conversion efficiency (FCE), feed intake (FI) and PER all showed significant discrepancies between green and white sea cucumber $(p<0.05)$. However, no significant difference between diet treatments was observed for white sea cucumber $(p<0.05)$. Three-way ANOVA also showed no significant interaction of the factors on proximate composition of sea cucumber $(p>0.05)$, while crude protein was significantly affected by the interaction of species and experimental time $(\mathrm{p}<$ 0.05) (Table 3). The body wall production rate (BWPR) and crude protein content of white sea cucumber were significantly higher than those of green sea cucumber $(p<0.05)$. There was no significant difference in moisture or crude lipid content between green and white sea cucumber or between the diet treatments $(\mathrm{p}<0.05)$.

\section{Nitrogen isotopic turnover}

Temporal changes in the observed $\delta^{15} \mathrm{~N}$ values of green and white sea cucumber fed the single natural diet of $S$. thunbergii and premixed artificial diet are shown in Figs. 1 \& 2, respectively. All the observed $\delta^{15} \mathrm{~N}$ values in sea cucumber tissues gradually increased owing to assimilation of the experimental

Table 2. Growth performance and feed utilization of green and white sea cucumber fed the experimental diets. $W_{\mathrm{f}}$ : final dry weight; weight gain $=\left(W_{\mathrm{f}}-W_{\mathrm{i}}\right) / W_{\mathrm{f}} \times 100 ;$ specific growth rate, $\mathrm{SGR}=\ln \left(W_{\mathrm{f}} / W_{\mathrm{i}}\right) / t \times 100 ;$ food conversion efficiency, FCE $=\left(W_{\mathrm{f}}-W_{\mathrm{i}}\right) /$ dry diet consumed $\times 100$; protein efficiency ratio, $\mathrm{PER}=\left(W_{\mathrm{f}}-W_{\mathrm{i}}\right) /$ protein intake; feed intake, FI $=$ dry diet consumed $/\left(\left[W_{\mathrm{f}}+W_{\mathrm{i}}\right] / 2 \times t\right)$. Different superscript capital letters within the same column indicate significant differences between the diets for the same color morph $(\mathrm{p}<0.05)$; different lowercase letters indicate significant differences between the color morphs fed the same $\operatorname{diet}(\mathrm{p}<0.05) .{ }^{*} \mathrm{p}<0.05{ }^{* *} \mathrm{p}<0.01$; ${ }^{* * *} \mathrm{p}<0.001$; ns: non-significant

\begin{tabular}{|c|c|c|c|c|c|c|c|c|}
\hline & Species & Survival (\%) & $W_{\mathrm{f}}(\mathrm{g})$ & Weight gain (\%) & $\operatorname{SGR}\left(\% d^{-1}\right)$ & FCE $(\%)$ & PER & FI $\left(g^{-1} d^{-1}\right)$ \\
\hline \multirow{2}{*}{$\begin{array}{l}\text { Sargassum thunbergii } \\
\text { diet }\end{array}$} & Green & $90.76 \pm 4.18$ & $1.36 \pm 0.08^{\mathrm{Aa}}$ & $66.92 \pm 1.94^{\mathrm{Aa}}$ & $1.13 \pm 0.06^{\mathrm{Aa}}$ & $5.99 \pm 0.12^{\mathrm{Aa}}$ & $0.29 \pm 0.01^{\mathrm{Aa}}$ & $0.21 \pm 0.02^{\mathrm{a}}$ \\
\hline & White & $91.02 \pm 5.50$ & $0.86 \pm 0.07^{\mathrm{b}}$ & $47.91 \pm 3.15^{\mathrm{b}}$ & $0.67 \pm 0.06^{\mathrm{b}}$ & $4.37 \pm 0.31^{\mathrm{b}}$ & $0.21 \pm 0.02^{\mathrm{b}}$ & $0.15 \pm 0.01^{b}$ \\
\hline \multirow[t]{2}{*}{ Artificial diet } & Green & $92.24 \pm 6.69$ & $1.17 \pm 0.05^{\mathrm{Ba}}$ & $61.09 \pm 0.95^{\mathrm{Ba}}$ & $0.98 \pm 0.03^{\mathrm{Ba}}$ & $5.29 \pm 0.20^{\mathrm{Ba}}$ & $0.25 \pm 0.01^{\mathrm{Ba}}$ & $0.19 \pm 0.02^{\mathrm{a}}$ \\
\hline & White & $90.33 \pm 3.57$ & $0.83 \pm 0.06^{\mathrm{b}}$ & $45.46 \pm 3.53^{\mathrm{b}}$ & $0.62 \pm 0.07^{\mathrm{b}}$ & $4.02 \pm 0.33^{\mathrm{b}}$ & $0.19 \pm 0.03^{b}$ & $0.14 \pm 0.02^{\mathrm{b}}$ \\
\hline \multicolumn{9}{|l|}{ Three-way ANOVA } \\
\hline Diet & & ns & * & * & ns & * & ns & ns \\
\hline Species & & ns & *** & ** & * & ** & * & * \\
\hline Time & & ns & * & ** & ns & ns & ns & ns \\
\hline Diet $\times$ Species & & ns & ns & ns & ns & ns & ns & ns \\
\hline Diet $\times$ Time & & ns & ns & ns & ns & ns & ns & ns \\
\hline Species $\times$ Time & & ns & * & * & ns & ns & * & ns \\
\hline Diet $\times$ Species $\times$ Time & & ns & ns & ns & ns & ns & ns & ns \\
\hline
\end{tabular}


Table 3. Proximate composition of green and white sea cucumber (wet weight, \%) fed the experimental diets. Body wall production rate, $B W P R=($ body wall weight $/$ total weight $) \times 100$. Different lowercase letters indicate significant differences between the color morphs fed the same diet $(\mathrm{p}<0.05) .{ }^{*} \mathrm{p}<0.05{ }_{i}{ }^{* *} \mathrm{p}<0.01 ;$ ns: non-significant

\begin{tabular}{|c|c|c|c|c|c|c|}
\hline & Species & BWPR $(\%)$ & Moisture & Crude protein & Crude lipid & Ash \\
\hline \multirow[t]{2}{*}{ Sargassum thunbergii diet } & Green & $61.08 \pm 1.35^{\mathrm{a}}$ & $90.23 \pm 1.08$ & $4.21 \pm 0.12^{\mathrm{a}}$ & $0.26 \pm 0.06$ & $2.98 \pm 0.11^{\mathrm{a}}$ \\
\hline & White & $66.64 \pm 2.07^{\mathrm{b}}$ & $91.18 \pm 1.45$ & $4.76 \pm 0.07^{\mathrm{b}}$ & $0.22 \pm 0.08$ & $2.54 \pm 0.10^{\mathrm{b}}$ \\
\hline \multirow[t]{2}{*}{ Artificial diet } & Green & $60.12 \pm 3.12^{\mathrm{a}}$ & $90.37 \pm 1.34$ & $4.17 \pm 0.09^{\mathrm{a}}$ & $0.27 \pm 0.03$ & $2.89 \pm 0.08^{\mathrm{a}}$ \\
\hline & White & $66.31 \pm 1.97^{b}$ & $92.04 \pm 2.19$ & $4.65 \pm 0.13^{\mathrm{b}}$ & $0.23 \pm 0.02$ & $2.61 \pm 0.06^{b}$ \\
\hline \multicolumn{7}{|l|}{ Three-way ANOVA } \\
\hline Diet & & ns & ns & ns & ns & ns \\
\hline Species & & $*$ & ns & $* *$ & $\mathrm{~ns}$ & $*$ \\
\hline Time & & * & ns & * & ns & ns \\
\hline Diet $\times$ Species & & ns & ns & ns & ns & ns \\
\hline Diet $\times$ Time & & ns & ns & ns & ns & ns \\
\hline Species $\times$ Time & & ns & ns & $*$ & ns & ns \\
\hline Diet $\times$ Species $\times$ Time & & ns & ns & ns & $\mathrm{ns}$ & ns \\
\hline
\end{tabular}

diets with higher nitrogen stable isotope ratios. There were significant shifts between the sampling time points $(\mathrm{p}<0.05)$. Significant differentiations in the nitrogen stable isotope signatures between green and white sea cucumber also commenced from the first week. Green sea cucumber had shorter halflives (for intestine, $T_{0.5}=14.98$ to $15.23 \mathrm{~d}$; for body wall, $T_{0.5}=29.66$ to $33.68 \mathrm{~d}$ ) compared to white sea cucumber (for intestine, $T_{0.5}=25.77$ to $34.25 \mathrm{~d}_{\text {; }}$ for body wall, $T_{0.5}=51.73$ to $60.80 \mathrm{~d}$ ) according to the calculations of the time-based turnover model (Table 4). Sea cucumbers fed S. thunbergii showed shorter half-lives than those fed the artificial diet, except for the intestine of green sea cucumber, and the half-lives were significantly affected by the interaction of diet and species for intestine and body wall $(p<0.05)$. The turnover rates in the intestine of sea cucumber fed $S$. thunbergii and artificial diet $\left(T_{0.5}=\right.$ 14.98 to $34.25 \mathrm{~d}$ ) were faster than that of the body wall $\left(T_{0.5}=29.66\right.$ to $\left.60.80 \mathrm{~d}\right)$.

In Figs. $3 \& 4$, the turnover rates with the contribution of growth and metabolism (solid lines) were significantly faster relative to those owing to growth alone (dotted lines) $(p<0.05)$. Metabolic contributions to the nitrogen isotopic turnover reached approximately 71 to $78 \%$ and 46 to $52 \%$ for intestine and body wall of sea cucumber, respectively. Nonsignificant differences in the $P_{\mathrm{m}}$ values between the diets and between the color morphs were found $(\mathrm{p}>$ $0.05)$. The final asymptotic nitrogen isotopic values $\left(\delta_{\mathrm{f}}\right)$ of the sea cucumbers fed $S$. thunbergii were significantly higher than those fed the artificial diet $(\mathrm{p}<$
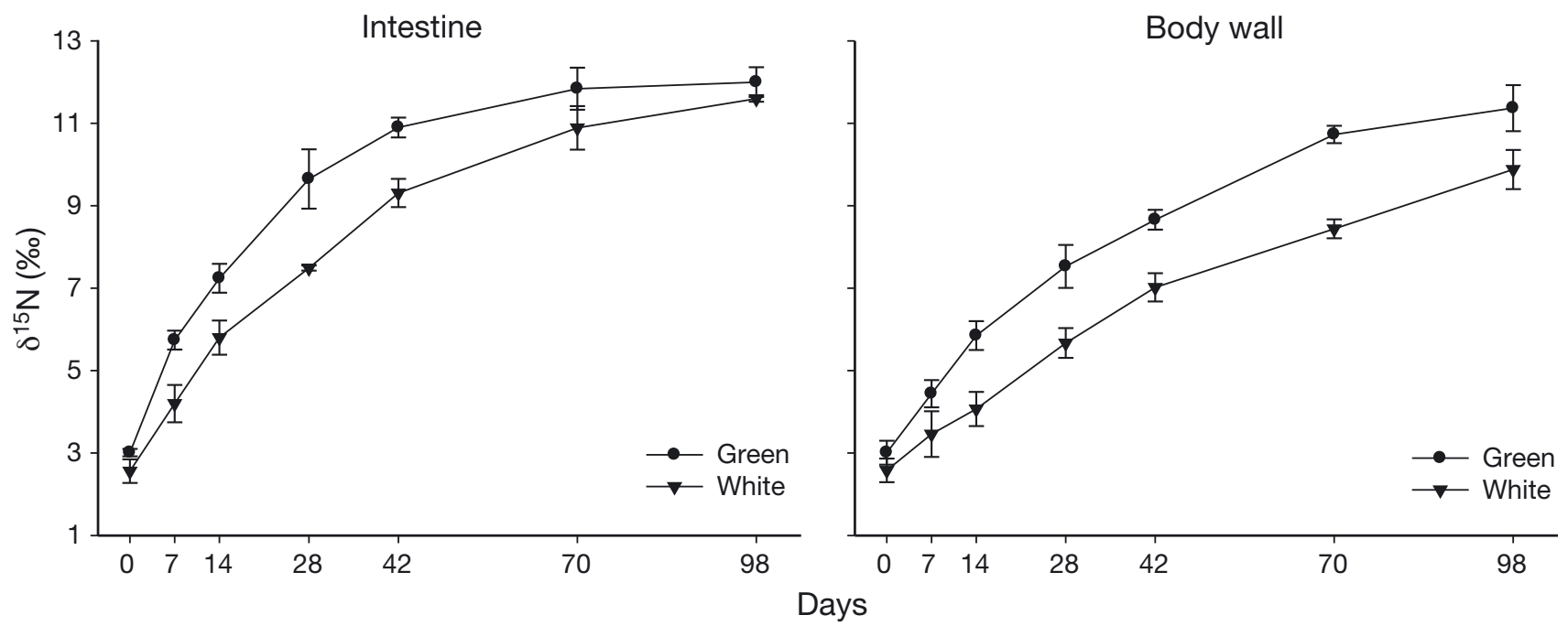

Fig. 1. Temporal changes in the observed $\delta^{15} \mathrm{~N}$ values for intestine and body wall of green and white sea cucumber fed single natural diet of Sargassum thunbergii 

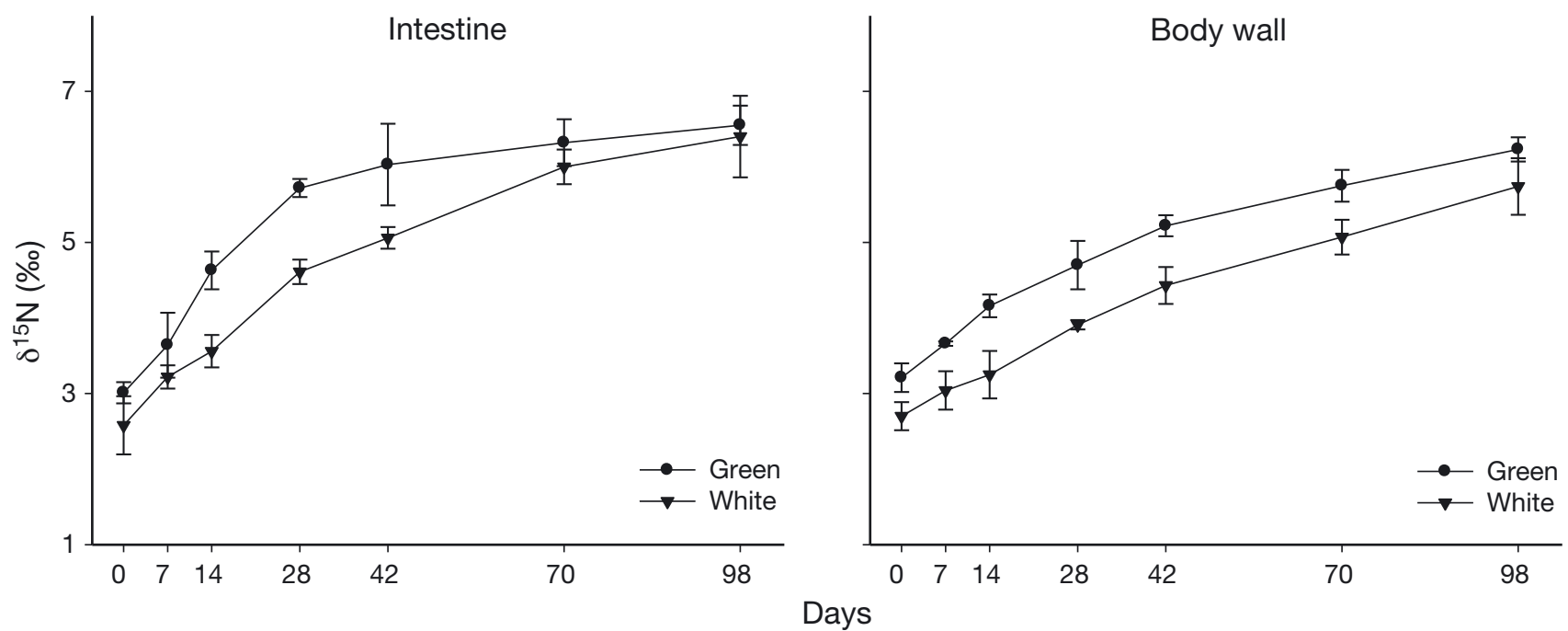

Fig. 2. Temporal changes in the observed $\delta^{15} \mathrm{~N}$ values for intestine and body wall of green and white sea cucumber fed a premixed artificial diet

0.05). According to the time-based turnover model, the estimated fractionation $\left(\Delta^{15} \mathrm{~N}\right)$ ranged from 2.37 to $3.30 \%$ in the present study (Table 4 ).

\section{Energy budget}

Energy parameters and budget of green and white sea cucumber fed $S$. thunbergii and artificial diet are shown in Table 5. During the experiment, the consumed energy of green sea cucumber was significantly higher than that of white sea cucumber $(\mathrm{p}<$ 0.05). Two-way ANOVA indicated significant interaction between diet and species in energy for growth ( $p<0.05)$. Green sea cucumber fed $S$. thunbergii had higher energy for growth than those fed the artificial diet $(p<0.05)$. The energy of feces produced and lost through ammonia excretion of green sea cucumber was significantly lower than those of white sea cucumber, which had lower energy deposited for respiration $(p<0.05)$. The average formulas for energy allocation in green and white sea cucumber were: $100 C=7.8 G+53.1 F+6.2 U+32.8 R$, and $100 C=6.3 G$ $+57.9 F+8.9 U+27.0 R$, respectively.

\section{DISCUSSION}

In the present study, green and white sea cucumber both exhibited obvious growth and nutritional suitability of various protein sources. The relatively lower growth performance and feed utilization of white sea cucumber was likely due to its lower digestive and immune enzyme activities (Xia 2012). Our

Table 4. Parameter estimate and calculation from the time-based model of $\delta^{15} \mathrm{~N}$ turnover for green and white sea cucumber fed the experimental diets. $m$ : metabolic turnover constant; $k$ : growth constant; $P_{\mathrm{m}}$ : proportion of metabolic contribution to nitrogen turnover; $T_{0.5}$ : time-based half-life; $T_{0.95}$ : time needed to reach $95 \%$ nitrogen turnover; $\delta_{\mathrm{f}}$ : final asymptotic nitrogen isotopic value; $\Delta$ : fractionation between diet and tissue. Different superscript capital letters within the same row indicate significant differences between diets for the same color morph ( $p<0.05$ ); different lowercase letters indicate significant differences between color morphs fed the same diet $(p<0.05)$

\begin{tabular}{|c|c|c|c|c|c|c|c|c|}
\hline Tissue/Diet & Species & $m\left(\mathrm{~d}^{-1}\right)$ & $k+m\left(\mathrm{~d}^{-1}\right)$ & $P_{\mathrm{m}}$ & $T_{0.5}(\mathrm{~d})$ & $T_{0.95}(\mathrm{~d})$ & $\delta_{\mathrm{f}}(\% \circ)$ & $\Delta(\%)$ \\
\hline \multicolumn{9}{|l|}{ Intestine } \\
\hline \multirow[t]{2}{*}{ Sargassum thunbergii } & Green & $0.0351 \pm 0.0022^{\mathrm{a}}$ & $0.0463 \pm 0.0013^{\mathrm{a}}$ & $0.75 \pm 0.03$ & $14.98 \pm 0.61^{\mathrm{a}}$ & $64.71 \pm 3.20^{\mathrm{a}}$ & $12.14 \pm 0.26^{\mathrm{A}}$ & 2.37 \\
\hline & White & $0.0201 \pm 0.0015^{\mathrm{Ab}}$ & $0.0269 \pm 0.0018^{\mathrm{Ab}}$ & $0.75 \pm 0.02$ & $25.77 \pm 0.52^{\mathrm{Ab}}$ & $111.37 \pm 7.34^{\mathrm{Ab}}$ & $12.34 \pm 1.60^{\mathrm{A}}$ & 2.56 \\
\hline \multirow[t]{2}{*}{ Artificial diet } & Green & $0.0357 \pm 0.0009^{\mathrm{a}}$ & $0.0455 \pm 0.0024^{\mathrm{a}}$ & $0.78 \pm 0.03$ & $15.23 \pm 0.97^{\mathrm{a}}$ & $65.83 \pm 4.37^{\mathrm{a}}$ & $6.57 \pm 0.19^{\mathrm{B}}$ & 2.45 \\
\hline & White & $0.0141 \pm 0.0012^{\mathrm{Bb}}$ & $0.0203 \pm 0.0008^{\mathrm{Bb}}$ & $0.71 \pm 0.07$ & $34.25 \pm 0.61^{\mathrm{Bb}}$ & $148.33 \pm 7.67 \mathrm{Bb}$ & $7.04 \pm 0.23^{\mathrm{B}}$ & 2.93 \\
\hline \multicolumn{9}{|l|}{ Body wall } \\
\hline \multirow[t]{2}{*}{ S. thunbergii } & Green & $0.0121 \pm 0.0035^{\mathrm{a}}$ & $0.0234 \pm 0.0014^{\mathrm{a}}$ & $0.51 \pm 0.06$ & $29.66 \pm 0.39^{\mathrm{Aa}}$ & $127.39 \pm 5.91^{\mathrm{Aa}}$ & $12.29 \pm 0.71^{\mathrm{A}}$ & 2.59 \\
\hline & White & $0.0067 \pm 0.0020^{b}$ & $0.0134 \pm 0.0021^{b}$ & $0.50 \pm 0.04$ & $51.73 \pm 1.28^{\mathrm{Ab}}$ & $223.56 \pm 6.60^{\mathrm{Ab}}$ & $12.51 \pm 0.28^{\mathrm{A}}$ & 2.77 \\
\hline \multirow[t]{2}{*}{ Artificial diet } & Green & $0.0108 \pm 0.0018^{\mathrm{a}}$ & $0.0206 \pm 0.0022^{\mathrm{a}}$ & $0.52 \pm 0.09$ & $33.68 \pm 1.47^{\mathrm{Ba}}$ & $145.57 \pm 8.93^{\mathrm{Ba}}$ & $6.64 \pm 0.51^{\mathrm{B}}$ & 2.54 \\
\hline & White & $0.0047 \pm 0.0005^{\mathrm{b}}$ & $0.0104 \pm 0.0008^{b}$ & $0.46 \pm 0.10$ & $60.80 \pm 2.01^{\mathrm{Bb}}$ & $271.49 \pm 11.48^{\mathrm{Bb}}$ & $7.42 \pm 0.53^{\mathrm{B}}$ & 3.30 \\
\hline
\end{tabular}




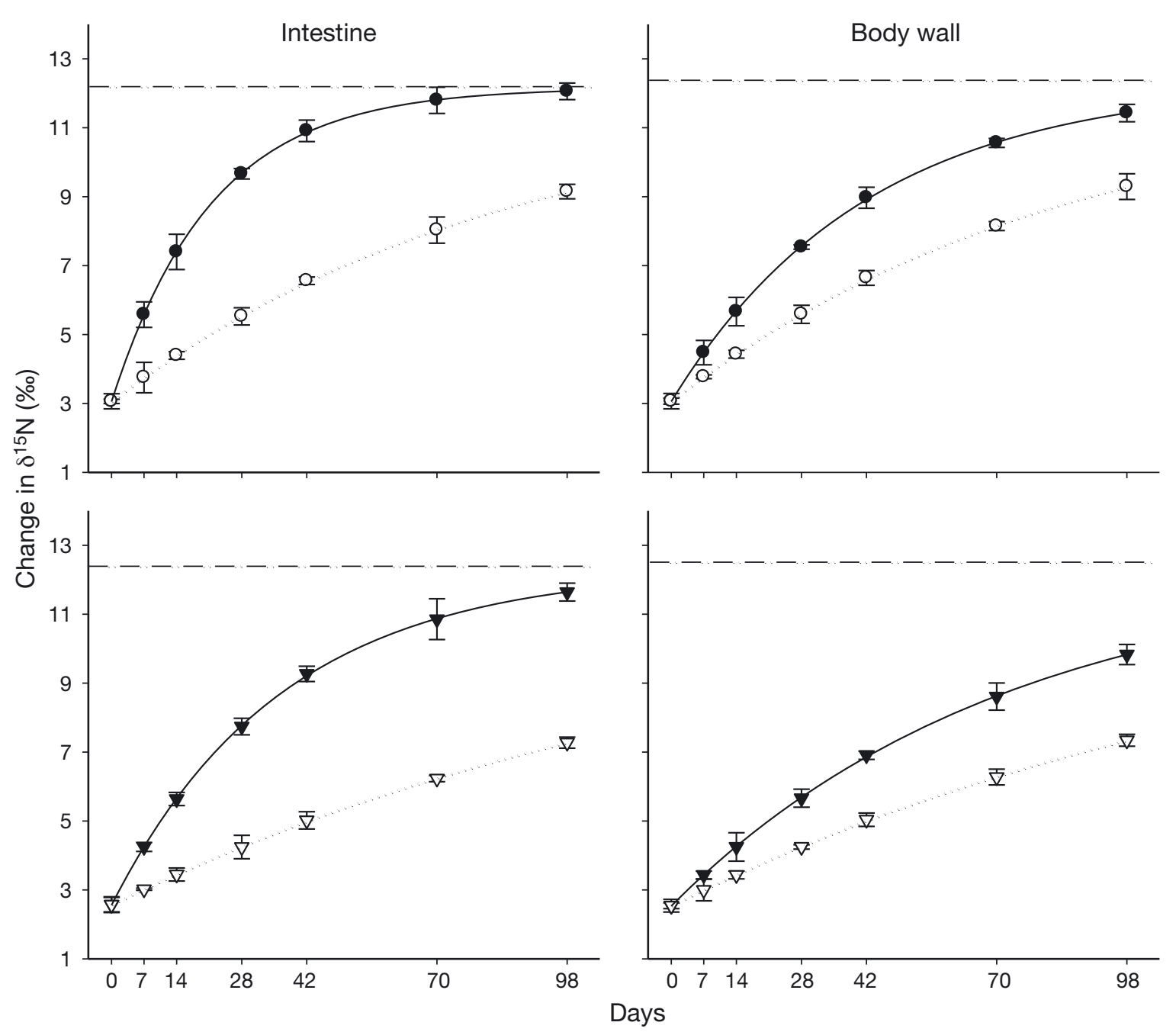

Fig. 3. Changes in the $\delta^{15} \mathrm{~N}$ values estimated with time-based turnover model for intestine (left column) and body wall (right column) of green (circles) and white sea cucumber (triangles) fed a single natural diet of Sargassum thunbergii. Solid lines/filled symbols: $\delta^{15} \mathrm{~N}$ values with the contribution of growth and metabolism; dotted lines/open symbols: $\delta^{15} \mathrm{~N}$ values with the contribution of growth alone (metabolic turnover constant, $m=0$ ). Horizontal dash-dotted line: expected $\delta^{15} \mathrm{~N}$ values when tissues are completely equilibrated to $S$. thunbergii

results found that feed intake and energy deposited for growth in white sea cucumber were significantly lower than those of green sea cucumber. The higher SGR, FCE and PER of green sea cucumber demonstrated preferential absorption of Sargassum thunbergii, while white sea cucumber, which was also fed the 2 experimental diets, showed no preference. The significant interaction of species and experimental time revealed that weight gain and PER of sea cucumber increased as its body weight increased. Experimental time also had significant effect on BWPR and crude protein content, as reported by Song et al. (2009).

Stable isotope analysis can be used for studying the protein catabolism and anabolism of aquatic organisms through straightforward procedures with rapid sample analysis and high accuracy (Abimorad et al.
2014). Generally, the turnover rate of stable isotopes in tissue reflects the rate at which the isotopic signature of a consumer changes with diet (Guelinckx et al. 2007, Xia et al. 2015a). In the present study, green sea cucumber approached the $\delta^{15} \mathrm{~N}$ values of the experimental diets much more quickly, hence had shorter half-lives compared to white sea cucumber. We speculate that protein turnover might be responsible for the discrepancies in crude protein between green and white sea cucumber, which should be further discussed in a future study. Due to variation in biochemical components and enzyme systems, the turnover rate of nitrogen stable isotope in the intestine of sea cucumber was faster than that of the body wall. Previous studies have found much faster isotopic turnover rates and shorter half-lives of stable 


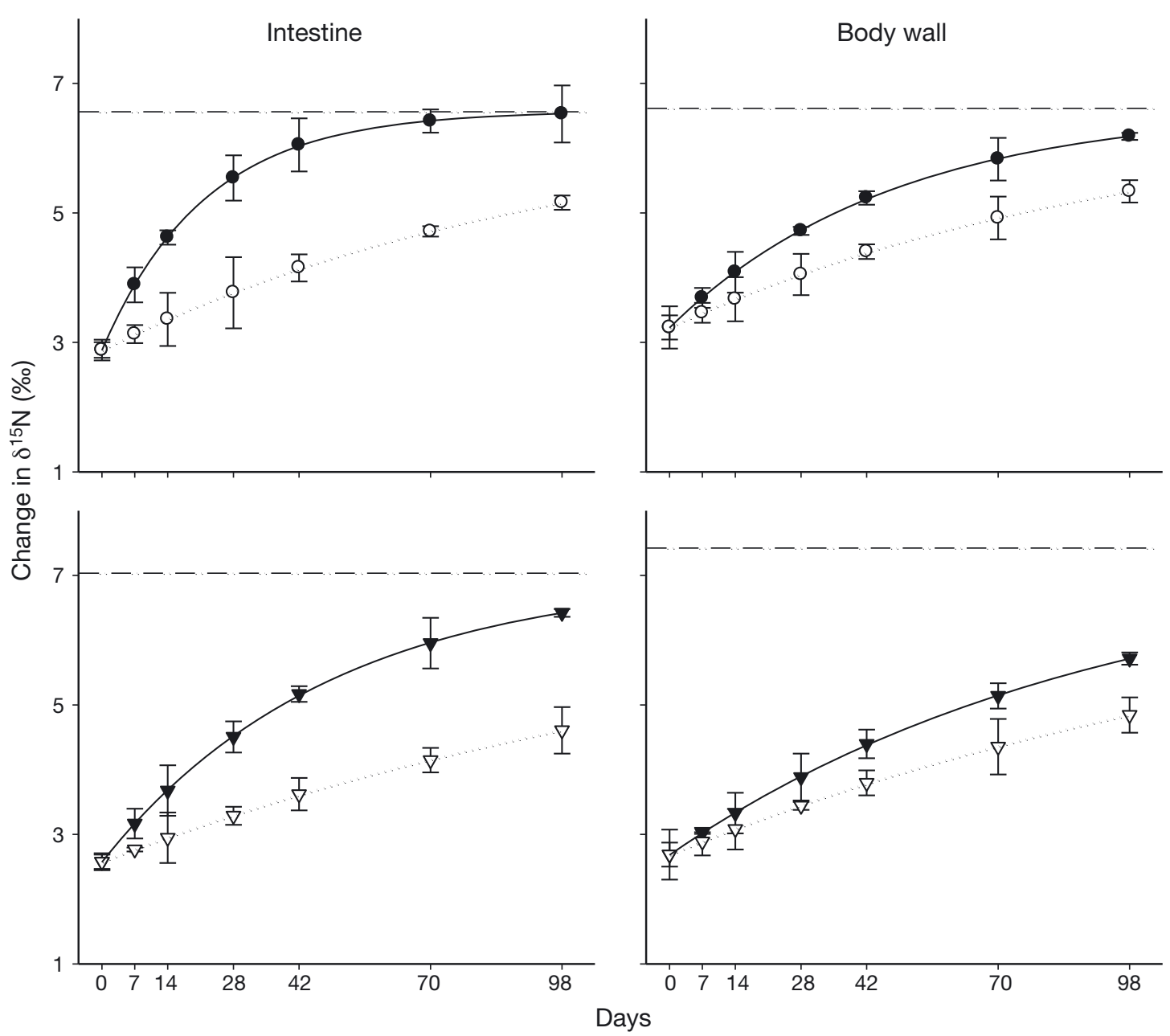

Fig. 4. Changes in the $\delta^{15} \mathrm{~N}$ values estimated with time-based turnover model for intestine (left column) and body wall (right column) of green (circles) and white sea cucumber (triangles) fed a premixed artificial diet. Solid lines/filled symbols: $\delta^{15} \mathrm{~N}$ values with the contribution of growth and metabolism; dotted lines/open symbols: $\delta^{15} \mathrm{~N}$ values with the contribution of growth alone (metabolic turnover constant, $m=0$ ). Horizontal dash-dotted line: expected $\delta^{15} \mathrm{~N}$ values when tissues are completely equilibrated to artificial diet

isotopes in vigorous metabolic tissues (Tarboush et al. 2006, Sun et al. 2012). Our results also proved that variable growth and metabolic contributions to the isotopic turnover process resulted in the differentiations in turnover rate of nitrogen stable isotope (Arneson \& MacAvoy 2005).

Tissue turnover is mainly driven by catabolic breakdown and anabolic replacement processes, which depend on growth (synthesis in excess of breakdown) and metabolism (a balanced rate of breakdown and resynthesis) (Hesslein et al. 1993). Previous studies have demonstrated that the relative importance of growth versus metabolism in isotopic turn-
Table 5. Energy allocation of green and white sea cucumber fed the experimental diet. $C$ : energy consumed; $G$ : energy for growth; $F$ : energy of feces produced; $U$ : energy lost through ammonia excretion; $R$ : energy lost through respiration. Different superscript capital letters within the same row indicate significant differences between diets for the same color morph $(\mathrm{p}<0.05)$; different lowercase letters mean significant differences between color morphs fed the same diet $(\mathrm{p}<0.05)$

\begin{tabular}{|lcccc|}
\hline \multirow{2}{*}{ Parameter } & \multicolumn{2}{c}{$\begin{array}{c}\text { Sargassum } \\
\text { Green }\end{array}$} & White & \multicolumn{2}{c|}{ Artificial diet } \\
& & & Green & White \\
\hline$C\left(\mathrm{~kJ} \mathrm{~g}^{-1} \mathrm{~d}^{-1}\right)$ & $2.01 \pm 0.11^{\mathrm{a}}$ & $1.50 \pm 0.12^{\mathrm{b}}$ & $2.11 \pm 0.08^{\mathrm{a}}$ & $1.66 \pm 0.06^{\mathrm{b}}$ \\
$G\left(\% \mathrm{C}^{-1}\right)$ & $8.24 \pm 0.35^{\mathrm{Aa}}$ & $6.36 \pm 0.27^{\mathrm{b}}$ & $7.39 \pm 0.11^{\mathrm{Ba}}$ & $6.23 \pm 0.12^{\mathrm{b}}$ \\
$G\left(\mathrm{~kJ} \mathrm{~g}^{-1} \mathrm{~d}^{-1}\right)$ & $0.17 \pm 0.01^{\mathrm{a}}$ & $0.10 \pm 0.02^{\mathrm{b}}$ & $0.15 \pm 0.01^{\mathrm{a}}$ & $0.10 \pm 0.02^{\mathrm{b}}$ \\
$F\left(\% \mathrm{C}^{-1}\right)$ & $52.43 \pm 2.07^{\mathrm{a}}$ & $57.55 \pm 2.21^{\mathrm{b}}$ & $53.84 \pm 1.54^{\mathrm{a}}$ & $58.19 \pm 1.80^{\mathrm{b}}$ \\
$F\left(\mathrm{~kJ} \mathrm{~g}^{-1} \mathrm{~d}^{-1}\right)$ & $1.05 \pm 0.12$ & $0.86 \pm 0.07$ & $1.14 \pm 0.10$ & $0.97 \pm 0.08$ \\
$U\left(\% \mathrm{C}^{-1}\right)$ & $5.99 \pm 0.31^{\mathrm{a}}$ & $8.89 \pm 0.16^{\mathrm{b}}$ & $6.39 \pm 0.22^{\mathrm{a}}$ & $8.87 \pm 0.18^{\mathrm{b}}$ \\
$U\left(\mathrm{~kJ} \mathrm{~g}^{-1} \mathrm{~d}^{-1}\right)$ & $0.12 \pm 0.02$ & $0.13 \pm 0.02$ & $0.14 \pm 0.03$ & $0.15 \pm 0.01$ \\
$R\left(\% \mathrm{C}^{-1}\right)$ & $33.33 \pm 1.42^{\mathrm{a}}$ & $27.20 \pm 1.85^{\mathrm{b}}$ & $32.35 \pm 2.27^{\mathrm{a}}$ & $26.72 \pm 3.04^{\mathrm{b}}$ \\
$R\left(\mathrm{~kJ} \mathrm{~g}^{-1} \mathrm{~d}^{-1}\right)$ & $0.67 \pm 0.15^{\mathrm{a}}$ & $0.41 \pm 0.04^{\mathrm{b}}$ & $0.68 \pm 0.11$ & $0.44 \pm 0.07$ \\
\hline
\end{tabular}


over is related to the bioenergetic allocations of organisms (e.g. Xia et al. 2015a,b). In the present study, non-significant differences in the $P_{\mathrm{m}}$ were found between green and white sea cucumber and between the diet treatments, suggesting that sea cucumber maintained a relatively stable bioenergetic distribution strategy in their tissues. According to Beltrán et al. (2009) and Le Vay \& GamboaDelgado (2011), greater fractionation, low growth rate and high protein mobilization can occur in fish and crustaceans under conditions of low dietary protein quality. Therefore, the high $\Delta^{15} \mathrm{~N}$ values in the tissues of the white sea cucumber might imply high dietary quality requirement.

The energy budget provides a framework for the evaluation of various ways in which nutrients are utilized (Lawrence \& Lane 1982). The energy deposited for growth accounted for 7.39 to $8.24 \%$ of energy intake for green sea cucumber and 6.23 to $6.36 \%$ for white sea cucumber. Energy losses as feces and respiration were the main proportion of energy intake. White sea cucumber spent more energy in excretion and feces compared to green sea cucumber, whereas it deposited less energy in growth performance with lower metabolic activities. Previous studies found that higher percentage of energy loss resulted in a lower percentage of energy deposition in growth of Holothurians (Yuan et al. 2006, Zhang et al. 2012, Xia et al. 2013a). The higher energy deposited for growth and relatively lower energy loss of feces and excretion for green sea cucumber fed $S$. thunbergii also demonstrated the high dietary quality of S. thunbergii.

\section{CONCLUSIONS}

The single natural diet of Sargassum thunbergii and premixed artificial diet supplied sufficient energy for sea cucumber growth and metabolism. Both green and white sea cucumber fed the experimental diets maintained a relatively stable bioenergetic distribution strategy in their tissues. Our results also revealed that white sea cucumber might have higher dietary quality requirements for growth and metabolism compared to green sea cucumber, which implies increased nutrient pollution in waste discharge. To reverse this trend, more effective water treatment measures and more attention to detail in culture management are warranted. The present study yielded valuable information that should be of great interest to the culture of green and white sea cucumber.
Acknowledgements. This work was funded by the grants from the Modern Agriculture Industry System of Shandong Province of China (SDAIT-22-04 and SDAIT-12-05) and the Promotive Research Fund for Young and Middle-aged Scientists of Shandong Province (BS2015HZ004).

\section{LITERATURE CITED}

Abimorad EG, Ducatti C, Castellani D, Jomori RK, Portella MC, Carneiro DJ (2014) The use of stable isotopes to investigate the effects of supplemental lysine and methionine on protein turnover and amino acid utilization in pacu, Piaractus mesopotamicus, juveniles. Aquaculture 433:119-124

AOAC (1995) Official methods of analysis of AOAC International, $16^{\text {th }}$ edn. AOAC International, Arlington, VA

Arneson LS, MacAvoy SE (2005) Carbon, nitrogen and sulfur diet-tissue discrimination in mouse tissues. Can J Zool 83:989-995

Bai YC, Zhang LB, Liu SL, Ru XS and others (2015) The effect of salinity on the growth, energy budget and physiological performance of green, white and purple color morphs of sea cucumber, Apostichopus japonicus. Aquaculture 437:297-303

Beltrán M, Fernández-Borrás J, Médale F, Pérez-Sánchez J, Kaushik S, Blasco J (2009) Natural abundance of ${ }^{15} \mathrm{~N}$ and ${ }^{13} \mathrm{C}$ in fish tissues and the use of stable isotopes as dietary protein tracer in rainbow trout and gilthead sea bream. Aquacult Nutr 15:9-18

* Buchheister A, Latour RJ (2010) Turnover and fractionation of carbon and nitrogen stable isotopes in tissues of a migratory coastal predator, summer flounder (Paralichthys dentatus). Can J Fish Aquat Sci 67:445-461

Gamboa-Delgado J, Rojas-Casas MG, Nieto-López MG, Cruz-Suárez LE (2013) Simultaneous estimation of the nutritional contribution of fish meal, soy protein isolate and corn gluten to the growth of Pacific white shrimp (Litopenaeus vannamei) using dual stable isotope analysis. Aquaculture 380-383:33-40

Kao QF, Wang YS, Dong SL, Sun ZL, Wang F (2011) Absorption of different food sources by sea cucumber Apostichopus japonicus (Selenka) (Echinodermata: Holothuroidea): evidence from carbon stable isotope. Aquaculture 319:272-276

Guelinckx J, Maes J, Van Den Driessche P, Geysen B, Dehairs F, Ollevier F (2007) Changes in $\delta^{13} \mathrm{C}$ and $\delta^{15} \mathrm{~N}$ in different tissues of juvenile sand goby Pomatoschistus minutus: a laboratory diet-switch experiment. Mar Ecol Prog Ser 341:205-215

*Hesslein RH, Haallard KA, Ramlal P (1993) Replacement of sulfur, carbon and nitrogen in tissue of growing broad whitefish (Coregonus nasus) in response to a change in diet traced by $\delta^{34} \mathrm{~S}, \delta^{13} \mathrm{C}, \delta^{15} \mathrm{~N}$. Can J Fish Aquat Sci 50: 2071-2076

Kang JH, Kim YK, Kim MJ, Park JY and others (2011) Genetic differentiation among populations and color variants of sea cucumbers (Stichopus japonicus) from Korea and China. Int J Biol Sci 7:323-332

KKanno M, Suyama Y, Li Q, Kijima A (2006) Microsatellite analysis of Japanese sea cucumber, Stichopus (Apostichopus) japonicus, supports reproductive isolation in color variants. Mar Biotechnol (NY) 8:672-685

Lawrence JM, Lane JM (1982) The utilization of nutrients by postmetamorphic echinoderms. In: Jangoux M, Lawrence JM (eds) Echinoderm nutrition. AA Balkema Publishers, Rotterdam, p 368-371 
Le Vay L, Gamboa-Delgado J (2011) Naturally-occurring stable isotopes as direct measures of larval feeding efficiency, nutrient incorporation and turnover. Aquaculture 315:95-103

Lin CG, Zhang LB, Liu SL, Gao S, Xu Q, Yang HS (2013) A comparison of the effects of light intensity on movement and growth of albino and normal sea cucumbers (Apostichopus japonicus Selenka). Mar Freshwat Behav Physiol 46:351-366

KLiu Y, Dong SL, Tian XL, Wang F, Gao QF (2009) Effects of dietary sea mud and yellow soil on growth and energy budget of the sea cucumber Apostichopus japonicus (Selenka). Aquaculture 286:266-270

Ma DY, Yang HS, Sun LN, Xu DX (2014a) Comparative analysis of transcriptomes from albino and control sea cucumbers, Apostichopus japonicus. Acta Oceanol Sin 33:55-61

Ma DY, Yang HS, Sun LN (2014b) Profiling and comparison of color body wall transcriptome of normal juvenile sea cucumber (Apostichopus japonicus) and those produced by crossing albino. J Ocean Univ China 13:1033-1042

Martin-Perez M, Fernandez-Borras J, Ibarz A, Felip O, Fontanillas R, Gutierrez J, Blasco J (2013) Naturally occurring stable isotopes reflect changes in protein turnover and growth in gilthead sea bream (Sparus aurata) juveniles under different dietary protein levels. J Agric Food Chem 61:8924-8933

MOAC (Ministry of Agriculture, China) (2016) China Fisheries Yearbook, 2015. China Agriculture Publisher, Beijing

Pei SR, Dong SL, Wang F, Tian XL, Gao QF (2012) Effects of density on variation in individual growth and differentiation in endocrine response of Japanese sea cucumber (Apostichopus japonicus Selenka). Aquaculture 356-357: 398-403

Seo JY, Lee SM (2011) Optimum dietary protein and lipid levels for growth of juvenile sea cucumber Apostichopus japonicus. Aquacult Nutr 17:e56-e61

Seo JY, Shin IS, Lee SM (2011) Effect of dietary inclusion of various plant ingredients as an alternative for Sargassum thunbergii on growth and body composition of juvenile sea cucumber Apostichopus japonicus. Aquacult Nutr 17:549-556

Shi C, Dong SL, Wang F, Gao QF, Tian XL (2013) Effects of four fresh microalgae in diet on growth and energy budget of juvenile sea cucumber Apostichopus japonicus (Selenka). Aquaculture 416-417:296-301

Shi C, Dong SL, Pei SR, Wang F, Tian XL, Gao QF (2015) Effects of diatom concentration in prepared feeds on growth and energy budget of the sea cucumber Apostichopus japonicus (Selenka). Aquacult Res 46:609-617

Sloan NA (1984) Echinorderm fisheries of the world: a review. Proceedings of the $5^{\text {th }}$ International Echinoderm Conference, 24-29 September 1984, Galway. AA Balkema Publishers, Rotterdam, p 109-124

Song ZD, Wang JY, Wang SX, Huang BS, Li PY, Zhang LM (2009) Comparative analyses of nutrient contents and composition of amino acid in body wall of Apostichopas japonicus in different developmental stages. Fish Sci Tech 36:11-13 (in Chinese)

SPSS (2008) SPSS v.16.0: student version for Windows. Prentice Hall, Upper Saddle River, NJ

Sun H, Liang M, Yan J, Chen B (2004) Nutrient requirements and growth of the sea cucumber, Apostichopus japonicus. In: Lovatelli A, Conand C, Purcell S, Uthicke
S, Hamel JF, Mercier A (eds) Advance in sea cucumber aquaculture and management. FAO Fisheries Technical Paper No. 463. FAO, Rome, p 327-332

* Sun ZL, Gao QF, Dong SL, Shin PKS, Wang F (2012) Estimates of carbon turnover rates in the sea cucumber Apostichopus japonicus (Selenka) using stable isotope analysis: the role of metabolism and growth. Mar Ecol Prog Ser 457:101-112

*Tarboush RA, MacAvoy SE, Macko SA, Connaughton V (2006) Contribution of catabolic tissue replacement to the turnover of stable isotopes in Danio rerio. Can J Zool 84: 1453-1460

* Wu B, Xia S, Rahman MM, Rajkumar M, Fu Z, Tan J, Yang A (2015) Substituting seaweed with corn leaf in diet of sea cucumber (Apostichopus japonicus): effects on growth, feed conversion ratio and feed digestibility. Aquaculture 444:88-92

Xia SD (2012) Researches on feeding behavior and dietary protein requirement of sea cucumber Apostichopus japonicus (Selenka). PhD thesis, Institute of Oceanology, Chinese Academy of Sciences, Qingdao

Xia SD, Yang HS, Li Y, Liu SL and others (2013a) Effects of differently processed diets on growth, immunity and water quality of the sea cucumber, Apostichopus japonicus (Selenka, 1867). Aquacult Nutr 19:382-389

Xia B, Gao QF, Li HM, Dong SL, Wang F (2013b) Turnover and fractionation of nitrogen stable isotope in tissues of grass carp Ctenopharyngodon idellus. Aquacult Environ Interact 3:177-186

Xia B, Wang JY, Gao QF, Sun YZ, Zhang LM, Ma JJ, Liu XQ (2015a) The nutritional contributions of dietary protein sources to tissue growth and metabolism of sea cucumber Apostichopus japonicus (Selenka): evidence from nitrogen stable isotope analysis. Aquaculture 435: 237-244

Xia B, Gao QF, Wang JY, Li PY, Zhang LM, Zhang ZD (2015b) Effects of dietary carbohydrate level on growth, biochemical composition and glucose metabolism of juvenile sea cucumber Apostichopus japonicus (Selenka). Aquaculture 448:63-70

Xia B, Ren YC, Wang JY, Sun YZ, Zhang ZD (2017) Effects of feeding frequency and density on growth, energy budget and physiological performance of sea cucumber Apostichopus japonicus (Selenka). Aquaculture 466: 26-32

Kuan XT, Yang HS, Zhou Y, Mao YZ, Zhang T, Liu Y (2006) The influence of diets containing dried bivalve feces and/or powdered algae on growth and energy distribution in sea cucumber Apostichopus japonicus (Selenka) (Echinodermata: Holothuroidea). Aquaculture 256:457-467

Zar JH (1999) Biostatistical analysis. Prentice Hall, Upper Saddle River, NJ

Zhang P, Dong SL, Wang F, Wang H, Gao W, Yan Y (2012) Effect of salinity on growth and energy budget of red and green colour variant sea cucumber Apostichopus japonicus (Selenka). Aquacult Res 43:1611-1619

Zheng F, Liu H, Sun X, Qu L, Liu J (2012) Selection, identification and application of antagonistic bacteria associated with skin ulceration and peristome tumescence of cultured sea cucumber Apostichopus japonicus (Selenka). Aquaculture 334-337:24-29

Zhu W, Mai KS, Zhang BG, Wang FZ, Xu GY (2005) Study on dietary protein and lipid requirement for sea cucumber, Stichopus japonicus. Mark Sci 29:54-58 (in Chinese with English Abstract) 